\title{
STATE CONTROL OF UTILITY CAPITALIZATION
}

\author{
IIAURICE C. WALTERSDORF
}

State control of the issuance of securities of public service corporations has developed by rather slow stages from an almost complete absence of control during the era of special charters to concentration of power in the hands of a commission. The present state laws dealing with the control of public utility capitalization consist of a few special charter acts, general statutes, and special public utility acts. Since the last type of law represents the most complete method of control, an analysis will be made of this group.

Control vested in special franchise acts or in general statutes invariably proves to be inadequate to properly control capitalization. Legislative control resulting from special charter acts usually fails to adequately safeguard the rights of the investor. Legislatures are not equipped for the task of proper security regulation. ${ }^{x}$ Few legislators possess the specialized knowledge and experience necessary to control such financial matters through the granting of special charter's by legislative enactment. Sound financial regulation also requires a non-partisan weighing of the facts in the case and a willingness to come to whatever conclusion the facts warrant. Too often legislative action is determined on the basis of certain promises made prior to election, and is not the result of evidence submitted in a specific case. Due also to an overcrowded legislative program, important legislation may be enacted during the closing days of a session with little or no consideration.?

Courts as a reliance in regulation have likewise their shortcomings. It is quite possible to pass general statutes that set up requirements such as are contained in typical modern public utility acts, and leave them to the courts for enforcement. MIany commonwealths have for a rather long period relied almost exclusively on this kind of machinery; but now substantially all the states have commissions which enforce the statute provisions dealing with the utilities, and a considerable number of these commissions have the power to regulate the issuance of securities. ${ }^{3}$ The shortcomings of the courts in this respect are only relatively fewer than those of the legislatures. Frequently

\footnotetext{
1 For further discussion, see White, The Origin of Utility Commiscions in Massachusetts (1921) 29 Jour. of POLITiCar EcoNosy 177-197.

2 Cf. Clatro, Soctal Control of Bustness (1926) 303.

${ }^{3}$ Commission control of securities is in vogue in all except twenty-five states.
} 
the costs of suits before a court are prohibitive to those who are most in need of protection. Court dockets may also be crowded. This all gives rise to the need for a more specific agency. Some body is needed which can render an expert opinion without throwing upon the plaintiff the cost and delay of court action with its expensive fees. It is sufficiently evident that some different agency is needed wherever the problem of regulation arises on a large scale involving numerous corporntions, many cases requiring elaborate records, ${ }^{4}$ and widespread individual complaints not worth the cost of expensive litigation. Needs of this character have brought into existence that outstanding governmental innovation known as the regulating commission. The commission is nominally an administrative body charged with carrying into effect the law as passed by the legislature. In practical effect, however, it combines legislative, executive, and judicial functions, and were it not for the fact that the legislature can withdraw the power it has conferred, and that the courts hold the ultimate right of judicial review, there might be danger through the use of this sort of control of having popular government replaced by bureaucracy. ${ }^{5}$

In eight states the commissions have been established by provisions of the constitution, and their powers defined and amplified by statute; in the other states the commissions have been created by legislative enactment. Delaware is the only state having no commission. In the case of twenty-four states no power has been conferred on the commissions to regulate the issuance of securities. ${ }^{6}$ As Delaware has no commission, there is thus a total of twenty-five states in which control of securities is absent. In the remaining states the laws impose upon the public service commissions the duty of regulating the issuance of securities by utility corporations, " and provide "that the approval and consent of the commission shall be necessary before any stocks, bonds, or evidences of indebtedness shall be issued." 8 All the commissions regulating securities except those of Massachusetts and Texas have been established since 1907. In general, the laws provide that the commissions shall approve only

4 Clark, op. cit. supra note 2 , at 304.

5 Ibid. 305.

- Alabama, Arkansas, Colorado, Connecticut, Florida, Idaho, Iowa, Kontucky, Louisiana, Minnesota, Mississippi, Montana, Nevada, New Mexico, North Carolina, North Dakota, Oklahoma, Oregon, South Carolina, South Dakota, Tennessee, Utah, Washington, and Wyoming.

"Arizona, California, District of Columbia, Georgia, Illinois, Indiann, Kansas, Maine, Maryland, Massachusetts, Michigan, Missouri, Nebraska, New Hampshire, New Jersey, New York, Ohio, Pennsylvania, Rhode Island, Texas, Vermont, Virginia, Wisconsin.

8 Cf. Heilman, Development by Commissions of the Principles of Publio Utility Capitalization (1915) 23 Jour. OF PoLITICAL ECONOMY 888. 
such issues of securities as are deemed reasonably necessary for certain purposes. The laws of the respective states differ in wording and detail, but apparently the principle common to all is that securities shall be issued only in such amounts as shall be necessary for purposes properly chargeable to capital account. The commissions are necessarily entrusted with a large degree of discretion, and have power's varying from publicity to absolute control. The Pennsylvania and Virginia commissions are of the pure publicity type. Their duties consist of the filing of notices of increases of securities. Four commissions have unrestricted control over security issues. These are the Vermont commission, which derives its authority from a general statute preventing over-capitalization, and the Arizona, California, and Illinois commissions, which obtain their power from detailed provisions in general public service commission acts. Ten of the commissions are required to ascertain the truth of the statements in the corporation's application for approval. ${ }^{9}$ The Texas law is rather stringent. It is enforced rigidly by imposing severe penalties upon a utility corporation for any infringement.

In nineteen states public utilities may issue securities only upon previous permission of the commission evidenced by a certificate of authority. ${ }^{10}$ Before such a certificate can be issued an application by the corporation for approval is necessary. The laws of several states contain only a very general clause, requiring a written application, ${ }^{11}$ while others outline the contents of the application, requiring items such as amount, character, purpose of the issue, terms of issue, and the description and estimated value of the property that is made the basis of the issues.22

Ordinarily, where an application is required for security issues by utilities, the commission carries on an investigation. ${ }^{23}$ If, after this investigation, the commission decides to permit an issue of securities, the certificate must, in several states, be recorded on the books of the company before securities may be

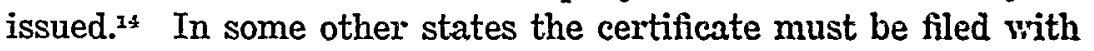

District of Columbia, Georgia, Indiana, Kansas, Maine, Maryland, Mrichigan, Missouri, Nebraska, and New Jersey.

10 The following states have this requirement: Arizona, California, District of Columbia, Georgia, Illinois, Indiana, Kansas, Maine, Margland, Massachusetts, Mijchigan, Mijssouri, Nebraska, New Hampshire, Now Jersey, New York, Ohio, Vermont, and Wisconsin. In Rhode Island such authority is required for the stock issues of street railways only.

11 Georgia, Maine, Mrassachusetts, Michigan, New Hampshire, and Vermont.

${ }^{12}$ Indiana, Kansas, Ohio, and Wisconsin.

${ }^{13}$ This is customary in Arizona, California, Georgia, Illinois, Mraine, Maryland, Michigan, Missouri, Nebraska, New Hampshire, New York, Ohio, Vermont, Wisconsin, and Pennsylvania in case of a certificate of valuation.

${ }_{14}$ District of Columbia, Kansas, Missouri, and Wisconsin. 
the Secretary of State. ${ }^{15}$ In this investigation the chief duty of the commissions is to see to it that the proposed securities to be issued are for legitimate purposes. Some states forbid the utilities to apply the proceeds of the securities to purposes other than those specified in the commission's certificate, ${ }^{10}$ or in excess of the amount there authorized. ${ }^{17}$ Most commissions having control over capitalization inquire at the outset whether the issue under consideration is for purposes which are in accord with the nature of the business carried on by the particular utility corporation. The commissions of Ohio and Vermont are authorized to reject applications if not convinced that the proceeds will be spent for the general good of the public. The acts of California, Arizona and Illinois permit the same interpretation. In Wisconsin the commission is vested with the power to require the utility to perform any act necessary to carry out the provisions of the law. Certain states allow their commissions to establish such rules and regulations as in their judgment are reasonable and necessary to prevent the disposition of the proceeds for purposes other than those designated in the order. ${ }^{18}$ The laws of some states also call for a detailed accounting of the proceeds. ${ }^{19}$

Securities issued with the object of duplicating facilities are not considered legitimate as to purpose by a number of the commissions. ${ }^{20}$ This position is undoubtedly justified, since unnecessary duplication of utility facilities results in reducing to scrap value much of the property of one or both companies. In such cases the burdens of the utility are increased and the public is not benefited. Commissions wherever possible should prevent the issuance of securities for unnecessary construction. The purposes generally specified by statute for which securities may be issued are the acquisition of property, the construction or extension of facilities, the improvement or maintenance of service, the discharge or refunding of lawful obligations, and the reimbursement of the treasury for moneys actually expended from income. ${ }^{21}$ Penalties are ordinarily provided for failure to observe any of the provisions in the act. These penalties operate against the securities issued, the corporations, and the officers and employees. The laws of nine states declare all securities void that

15 Texas, Massachusetts, and New Hampshire.

${ }_{16}$ Arizona, California, Illinois, Kansas, Massachusetts, Missouri, New Hampshire, New York, Ohio, and Wisconsin.

Ir Arizona, Califormia, and Illinois.

18 Arizona, California, Illinois, Missouri, and Wisconsin.

19 Arizona, California, Mllinois, and Missouri.

20 In re Turner Light \& Power Co., P. U. R. 1916A 418.

${ }^{21}$ Cf. Barron, State Regulation of Securities (1918) 76 ANNALs OF AM. ACADEMY of Political \& Soctal ScIENCE 167, 178-179. 
violate the law. ${ }^{22}$ Texas, ${ }^{23}$ California ${ }^{21}$ and New Hampshire ${ }^{25}$ require new applications, but Nebraska ${ }^{20}$ and Indiana ${ }^{27}$ validate such issues. There is a conflict of authority as to the commission's authority to take this latter course. The penalty imposed on the utility is usually a fine ranging from $\$ 500$ to $\$ 20,000$. In some states the agent may also be fined from $\$ 500$ to $\$ 10,000$ on a misdemeanor charge, and in other states he may be imprisoned for a term of fifteen years on a felony charge. In Texas such an agent is personally responsible to the creditors for the full amount of the damage sustained.

The security issues of public service corporations subject to state control are usually defined as stocks, stock certificates, bonds, notes, trust certificates, and other evidences of indebtedness payable at more than twelve months after date. The public utility acts, it seems, do not enter into more detail, and this lack of an adequate definition has been a marlied deficiency characteristic of all the laws. It is also left to the discretion of the commissions to determine what constitutes an issue of such securities. All securities issued for periods of less than twelve months are ordinarily exempt from regulation. The Pennsylvania commission, however, may, at its own discretion, require a certificate of notification to be filed, while Wisconsin limits such proposed issues to those made for money; and requires its consent if issued for property or service. The other states place no restraint upon the issuance of such securities. The interstate character of a corporation or of a particular issue may also partially lead to exemption. Some state statutes confine regulation to domestic utilities. ${ }^{28}$ In such cases the securities of a foreign utility corporation need not be approved. Other states have laws which apply to all corporations transacting business within the state. ${ }^{29}$ In Georgia the law is so worded that it could be interpreted to apply to all such corporations, but the commission has refused to take jurisdiction over stocks issued by foreign corporations, or bonds issued by a utility engaged in interstate commerce. ${ }^{30}$

22 Arizona, Califormia, District of Columbia, Illinois, Kansas, Maine, Ohio, Texas, and Wisconsin.

23 Davis v. Watertown Nat. Bank, P. U. R. 1915E 531.

24 In re Oakland, A. \& E. R. R., P. U. R. 1915A 643; In re Escondido Utilities Co., Ibid. 1071.

25 In re Conway L. \& P. Co., P. U. R. 1915E 931.

$26 \mathrm{Re}$ Application of Firth Telephone Co., P. U. R. 1915C 24.

${ }_{2 \pi}$ In re Farmers' \& MI. Co-op. Telephone Co., P. U. R. 1915B 55.

28 IIaine, Maryland, Nebraska, New York, and Vermont.

29 District of Columbia, Kansas, Mlichigan, New Hampshire, Ohio, and Wisconsin.

30 See 25 Nat. Ass'n of Rathroad Commirssioners, Proceedings (1913) 172. 
Frequently, the location of the property used as the basis for the issue is made the measure of jurisdiction. The acts of Arizona, California and Missouri apply to all issues based upon property within the state. A commission ruling of Illinois holds likewise. Some commissions lose control if the proceeds are spent without the state. The laws of Massachusetts and New Hampshire exempt such part of an issue as represents expenditures outside of the state. The Ohio commission grants, but does not require, its approval if expenditures are to be made without the state. The Maryland commission ruled that it had full jurisdiction over all securities issued by domestic corporations, but the courts held that it had no control over securities whose proceeds were spent outside the state. ${ }^{31}$ Aside from these exceptions, the laws governing security issues apply to every form of security issue, including pledge, whether pertaining to new, existing, reorganized, or consolidated companies, and whether for property or services.

Presumably, the chief purpose of regulating utility securities is to avoid the evils of over-capitalization. Regulation, so far as possible, should aim to establish an equilibrium 'between capitalization and the bona fide investment. Over-capitalization increases the financial risk and accentuates the difficulty of obtaining capital for new additions and extensions. It may divert money that should be used for upkeep and renewals to pay dividends on fictitious stock. Fictitious capital may be used to conceal what otherwise would be an excessively high rate of return. If a company were earning a nominal high rate of return on a fair capitalization of its plant and equipment, public opinion probably would demand a lower return; but if the same corporation shows only a fair or normal rate of return on an over-capitalized structure, there will be fewer protests, and criticism of the rate of return might seem to be without valid foundation. ${ }^{32}$ In either case the return actually realized may be the same. Over-capitalization makes securities speculative and thus fails to attract bona fide investors who, in the last analysis, furnish the sort of capital demanded by modern largescale industry.

In connection with over-capitalization, the question frequently arises as to what should be done in cases where corporations were over-capitalized prior to the establishment of commission control over securities. A number of the commissions have taken a definite stand in regard to this question. The New York Second District Commission passed upon this question early in its history. The commission held that it had absolutely nothing to do

31 Laird v. Baltimore \& O. R. R., 121 MId. 179, 88 Atl. 348 (1913).

32 Cf. Holmes, Regulation of Ratiroads and Public Utulities in WisCONSIN (1915) 238. 
with the capitalization of the companies which had come into existence previous to its establishment. It maintained that its duty was to pass upon applications for nev securities, and to determine whether the new capital to be issued is for purposes that are right and proper under the law. ${ }^{33}$ The Ohio commission has similarly dealt with this problem. It has ruled that past offenses involving over-capitalization ". . . should not be regarded as a bar to future honest action, although the honest superstructure may of necessity be compelled to rest upon a dishonest foundation." 84 The New Jersey commission has taken a similar position, ruling that the intent of the public utility law is to prevent subsequent inflated issues. ${ }^{\circ}$ It seems that a majority of the commissions, including those of Indiana, Maryland, Nebraska, Michigan, Illinois, New Hampshire, Wisconsin, California, and Missouri approve new issues of securities regardless of the relation which existed between capitalization outstanding and the value of the property prior to commission control. While some commissions have not explicitly committed themselves on this issue, the position taken by those mentioned above appears to be generally accepted except in Massachusetts and Texas. The Massachusetts commission has followed the practice of refusing to approve new securities when the value of the property of the companies consolidated is less than the par value of the stock and funded debt outstanding. In some instances, this commission has found it necessary to waive this policy in the interests of the public. In general, however, it has not permitted further capitalization when over-capitalization already existed, although the expenditures might be for a legitimate and lawful purpose. The Texas Railroad Commission has regularly refused to allow new issues of securities, if the outstanding issues exceeded the value of the property. ${ }^{36}$ The rigid application of this policy in Texas has checked somewhat the building of extensions and investments in betterments by railroads. In Massachusetts this result has largely been prevented by the fact that the commission has permitted rates to be charged which have enabled the utilities to build up a surplus in the property out of earnings.

To require commissions to follow the practice of the Massachusetts commission and squeeze out all the water that has been

33 Watertown Light \& Power Co., 1 N. Y. PUB. SEr. Cosrar., 20 DisT., ANNUAL REP. FOR 1908, 11, 12.

34 OHIo PUB. Ser. CoMmr. Rep. (1912) 4.

35 N. J. BoARd OF Pub. Utח. CoMm., Conference Order No. 7, and Conference Ruling No. 13 (June, 1911).

36 TEX. R. R. CoMrM. REP. (1913) 442. In some instances separate capitalization of extensions has been permitted, which has lessened the severity of this policy. 
injected in the past before new securities may be issued would impose a great financial hardship upon many corporations. "Certain writers ${ }^{37}$ also feel that this principle would violate the elementary theories of American justice, and would establish an ex post facto practice, compelling, in substance, the elimination of capitalization the issuance of which was perfectly legal and countenanced by the states when it was made. While it would seem that, ordinarily, commissions should not endeavor to extend their regulatory power into the past, nevertheless past over-capitalization should not be ignored to the extent of permitting the issuance of additional securities by utility corporations which are tending toward bankruptcy, and which inevitably must go into the hands of a receiver. To permit this would, in all probability, inflict a loss upon those who purchase such securities. This principle has been recognized by the California commission. ${ }^{38}$

Consolidation of utility properties was often used to inflate capitalization before the establishment of government control over the issuance of public utility securities. It was often felt that it would be easier for a new corporation to float an excessive issue than for the separate companies to do so. Stockholders of merged companies were willing to avail themselves of the opportunity of exchanging their shares for larger shares in the new company. In those states which have undertaken rigidly to regulate securities, this practice is no longer possible. In these states capitalization cannot be increased through consolidation beyond that of the consolidated companies. In Ohio, ${ }^{30}$ for example, the law provides that the capital stock and aggregate debt of corporations formed by the consolidation of two or more corporations shall not exceed the sum of the capital stock and aggregate funded debt of the merged companies and any additional sum actually paid in cash. The laws of Maryland, ${ }^{40} \mathrm{Ne}-$ braska, ${ }^{41}$ New York, ${ }^{42}$ Illinois, ${ }^{43}$ and Indiana ${ }^{44}$ have the same provisions regarding capital stock, but they do not include the debt. In those states where statutes do not specifically cover the subject of capitalization of consolidation, the commissions have formulated certain principles to which they adhere in passing upon this phase of financial control.45

${ }^{37}$ Heilman, op. cit. supra note 8, at 891 .

${ }^{38}$ Application of United R. R. of San Francisco, 2 CAL. R. R. Comm., OPINIONS AND ORDERS FOR 1913, 140-148.

39 Ohio Gen. Code (Page, 1926) § 614-59.

$40 \mathrm{Md}$. Code (Bagby, 1924). Art. 23, §§ 381, 392.

11 Neb. Comp. Stat. (1922) \& 676.

12 N. Y. Cons. Laws (Cahill, 1923) c. 49, \$\$ 55, 69, 101.

43 Ill. Rev. Stat. (Smith, 1921) c. $1112 / 3$, \& 22.

$\$ 4$ Ind. Ann. Stat. (Burns, 1926) § 12763.

${ }^{45}$ Cf. Heilman, The Capitalization of Public Utility Consolidations (1017)

7 AM. ECONOMIC Rev. 187. 
The statutes referred to above provide that capital stock, or the stock and debt, of the new corporation shall not exceed that of the consolidated companies. While this principle is laudable, and there is nothing in the act of consolidation which justifies increasing the aggregate of capitalization, nevertheless it is a subject of controversy whether this principle goes far enough. It has frequently been maintained that a corporation which represents a consolidation of other companies, and which comes into possession of the properties of the consolidated companies, should be treated identically as a new utility is treated, and that the amount of capitalization authorized should be determined solely by the actual value of the property to be acquired by the consolidated utility enterprise. The Missouri commission has favored the principle that over-capitalization must be eliminated before permission will be given to consolidate. On the other hand the Arizona, ${ }^{47}$ Ohio, ${ }^{48}$ Maryland, ${ }^{49}$ and Kansas ${ }^{50}$ commissions are on record as approving applications for the issuance of securities in a consolidation process without ascertaining any valuation of the properties of the separate companies. This action was apparently justified by these commisisons on the ground that the capitalization of the properties involved was not increased by the consolidation. It is probable, in many cases, that if the capitalization of consolidated enterprises were made to correspond to the actual value of the properties included, the consolidation would not be effected, and the community would be deprived of the advantages arising from unified operation, such as more economical financing, lower operating expenses, and more efficient management. Consolidation, especially of smaller utilities, will often produce gains from which the public may derive the benefit, if a regulatory body exists with ample powers."s To require a consolidation to limit its capitalization to the actual value of the constituent properties would be retroactive, ${ }^{22}$ as it would in some cases require a corporation to wipe out all its past over-capitalization before permitting it to issue new securities for betterments and improvements.

If the states were required to permit a fair return on securities bearing their stamp of approval, then the whole situation regarding the capitalization of consolidation projects would be changed. In that event state authorization of securities would

16 IIo. Pub. Ser. Comin., Second Annual Rep. (1914) 85.

${ }^{47}$ Consolidation of El Paso \& S. W. R. R., ARIz. Conp. Coגns., Frnst ANNUAC REP. (1912-13) 825.

48 Application of Miami Light, H., \& P. Co. and Piqua Elect. Co., OHzo

PUB. UTII. CoMrMr. REP. (1913) 106.

10 Air. Tel. \& Tel. Co., Comisirssion Leaflet No. 16, 600.

50 Amr. Ter. \& TeL. Co., Commission leaflet No. 29 (1914) 793.

51 Heilman, op. cit. supra note 45, at 192.

52 Supra page 9. 
imply protection in rate making, and the petition of a consolidation to issue its securities would have to be treated exactly as the petition of a new enterprise. In other words, the amount of securities that could properly be issued would depend upon the actual value of the property. Under such circumstances any insistence upon the equivalence between the capitalization of a consolidation and the value of the constitutent properties could not be regarded in any sense as retroactive. However, since there is a lack of specific judicial determination regarding the degree of obligation a state assumes when it approves securities, it is reasonable to assume that a state is under no obligation to guarantee to investors any particular rate of return upon the securities it has permitted to be issued. This is the position taken by nearly all the commissions, ${ }^{63}$ and some public utility acts actually contain this provision. It would be a dangerous precedent for a state to guarantee investments in utility securities when it exercises a relatively small degree of control over the actual administration of corporate affairs. Approval of securities by a commission simply indicates that they are issued for purposes properly chargeable to capital account, that they are issued for purposes and in amounts reasonably necessary, that the corporation has secured assets which bear a proper relation to the amount of securities issued, and that the company gives evidence of being able to meet fixed charges upon bonds and notes. Beyond this it would be hazardous to assume that a commission's approval of securities constitutes a guaranty of them. Investments, even though they may be honestly and prudently made at the time of security approval, are not exempt from the possibility of subsequent ill fortune and disaster to which a company may succumb. If such control over securities carried with it the guarantee by the state of a fair return upon the securities approved, the burden of future bad fortune would be imposed upon the consumer in the form of relatively higher rates. Judicial determination doubtless would greatly simplify, not only capitalization as it pertains to consolidation, but the whole problem of regulation of utility securities. Rates, therefore, will presumably continue to be based upon the fair value of the property and not upon the securities approved by the state or its regulatory agent. ${ }^{.4}$

The feeling that capitalization should equal the physical value of the property has at times led to a protest against capitalizing working capital, $i$. e., the fund of ready money and sup-

53 The only commission that has definitely taken the stand of protecting the securities it has authorized is the Massachusetts Public Service Commission. See Heilman, T'wo Rate Discussions of Importance (1915) $29 \mathrm{Q}$. Jour. OF ECONOMICS 840.

54 Heilman, loc. cit. supra note 45. 
plies which a concern must have on hand in addition to its plant and equipment. The Massachusetts commission usually allows the issuance of securities for this purpose. The New York Second District Commission also sanctions such an issuance of securities. The amount that the commission allows to be capitalized in such cases will depend upon the extent of the operations carried on by the corporation.5 The Maryland, Missouri, New Jersey, and Indiana commissions have likewise recognized the propriety of providing adequate funds by means of issuing securities. Working capital is essential to provide for supplies which must be carried in stock, and to make advances for materials and wages. Since working capital is a part of the investment which is necessary to conduct the business, this item should be recognized as one that is properly subject to capitalization.

The commissions controlling security issues determine not only the total capitalization to be allowed, but also the proportion that should be maintained between stocks and bonds, and the proper amount of each. In MTassachusetts, a governing principle has been established by legislative enactment. The statute provides that railroads, street railways, and gas and electric utilities cannot issue bonds in excess of their capital stock. ${ }^{5}$ The New York Second District Commission has ruled that the maximum bond issue which it will approve is determined by the probable excess of earnings over the necessary expenses of operation, estimated on "a conservative basis of practical certainty" based upon a comparison of similar plants already in operation.: The New York First District Commission has followed a similar practice with the exception that it has authorized the issuance of stock when it was rather uncertain whether there would be any net income whatever: ${ }^{5 s}$ The New Jersey commission will not approve bond or note issues unless there is sufficient evidence that the fixed charges can be regularly met, and that the principle can be paid at maturity. When securities are to be issued by a plant already operating, the past and current earnings are considered as relevant. If the company is newly projected, bond or note issues will be approved only for such an amount as it appears that the company can, with average good manage-

55 Complaint of Trustees of Peeksville v. Peeksville L. \& R. R. Co., 1 N. Y. PUB. Ser. Comim., 2D Dist., ANnual Rep. for 1928, 265, 277, 278; N. Y. Tel. Co., Investigation of Rates, 1 N. Y. PUB. Serv. Comra., 2D DIST., ANNUAL REP. FOR 1924, 93, 140.

56 Miass. Rev. Laws (1921) c. $159, \S 53$; c. $160, \S 47$; c. 161 , 20 ; c. $164, \S 13$.

${ }^{57}$ Application of Rochester, C., E., Trac. Co., 1 N. Y. Pub. SEr Coxa., 20 Dist., ReP. of Decisions (1910) 166, 167, 187 et scq.

ss Petition of Mid-Crosstown Ry., 5 N. Y. PUB. SER. Comar, 1sr DisT., ReP. OF DeCISIONS (1914) 22 (Case No. 1714). 
ment, meet the fixed charges upon. ${ }^{59}$ The California commission condemns the construction of properties entirely from the proceeds of bond issues, ${ }^{60}$ and specifies 75 per cent of the total capitalization in the form of bonds as the maximum limit for a sound capitalization. ${ }^{61}$ In Iowa, Nebraska and Utah the maximum amount of bonds that can be issued is limited to two-thirds of the capital stock. In Arkansas, Maryland, Missouri, Nevada, and Ohio, bonds must not exceed the capital stock, while in certain other states the total indebtedness cannot exceed the capital stock. ${ }^{62}$ Connecticut limits the total indebtedness to the stock paid in, while Delaware, Massachusetts, Pennsylvania, and Washington permit bonds to be issued to twice the amount of the stock paid in.

It is impossible, of course, to make a rule as to the proper proportion of bonds that is uniformly applicable, due to differences in conditions. Ordinarily, property should not be constructed entirely from the proceeds of bonds, as this practice leads to insecure bonds, receiverships, a lack of responsibility on the part of shareholders, and other evils. The principle followed by the New York and New Jersey commissions is a safe and preferable one, in so far as the earnings which are "reasonably certain" can be properly estimated. Obviously insecure investments and foreclosures will be prevented if no bonds are issued upon which the interest would exceed the amounts reasonably certain to be earned. Commissions should not allow bonds to be issued in unduly large amounts, since bonds approved by the state will ordinarily secure a ready sale without careful investigation on the part of the investors, even though issued to such an excess as to lead to future receivership. While stock should not be authorized except for an amount which bears a proper relation to the value of assets owned or to be acquired, it is not so important that a commission should insist upon the same degree of assurance of a return upon stock as upon bonds. Stockholders knowingly forego the right to claim the definitely fixed rate of return which bondholders possess in return for the possibility of receiving a larger rate on their stock.

If the primary purpose in regulating securities is to prevent stock watering, then it is questionable whether commissions should permit securities to be sold at less than par, since securities sold at less than their face value will cause those outstanding

\footnotetext{
${ }^{59}$ N. J. BOARd of PUB. UTIL. Comm., Conference Order No. 728, and Conference Ruling No. 13 (1912-13).

${ }^{60}$ CAL. R. R. CoMM. REP. (1912) 308.

${ }^{61}$ Application of Livermore Water \& P. Co., 2 CAx. R. R. CoMm., OPINIONS AND ORDERS FOR 1913, 618-626 (Decision No. 578).

62 Idaho, North Dakota, Oklahoma, South Dakota, Washington, and Wyoming.
} 
to become greater in amount than the sum of capital actually invested in the enterprise. The policy followed by most commissions is to require stocks to sell at par, but to allow bonds to be sold at a discount. The Wisconsin and Indiana commissions permit bonds to be sold as low as 75. The Miassachusetts commission discourages the sale of bonds at less than par, and Texas prevents bonds from being sold at less than par. Miissouri has allowed bonds to be sold as low as 70, and Illinois for 73 . The New Jersey commission favors a minimum of 80, but requires stock to be sold at par, or, if stock is exchanged for property, the property must have a cash value equal to the par value of the stock. ${ }^{63}$ Michigan also favors a minimum of 80 . The New Hampshire law requires stocks, but not bonds, to be sold at par. The Maine commission has required both stocks and bonds to be sold at par, especially where a new corporation was involved.cs

Some commissions regularly authorize the sale of both stocks and bonds at a discount. The California and Georgia commissions permit this, while Ohio permits the latter to be sold at a discount.es Whether securities should be permitted to be sold at less than par depends somewhat upon the general policies governing a commission, and, especially, its principles of rate making. If the amount of securities authorized were taken as the basis for rates, then it is obvious that securities should not be sold at a discount. Mrassachusetts, it appears, has used the amount of securities as such a basis, and, therefore, her position, in demanding that securities be sold at no less than par, has been justified. However, no other commission has used the amount of securities outstanding as a basis for rate making, and therefore the selling of securities at a discount may be justified in these states. In certain cases it might be highly desirable that a utility be allowed to sell stock at less than par, for otherwise a company that would be unable to obtain par for its stocks could not issue new stock to add to its equipment or to construct extensions. Perhaps it is also so situated financially that further bond issues would be unwise or impossible. Such a condition might tempt a company to borrow funds with which to maintain dividends to keep the market value of stock from going below par. Such results have been produced, particularly before the era of regulation. This does not apply to a nev project which is not over-capitalized, has no securities outstanding, and whose earnings are not known. If an old established utility cannot advantageously sell its securities at par, it is probably preferable for a commission to see to it that they are sold at the best pos-

${ }_{63}$ N. J. BOARD OF PUB. UTr. Contar., Conference Order No. 7, and Conference Ruling No. 13 (June, 1911).

64 Re Application of the Black Stream Electric Co., P. U. R. 1915C 361.

65 In re Application of the Chardon Waterworlis Co., P. U. R. 1915A 551. 
sible price. In that instance the commission can prevent the issuance of more securities than are reasonably necessary for a given purpose, and at the same time desirable additions or improvements to existing properties will not be prevented.

If bonds are sold at a discount, it is ordinarily desirable that some plan be evolved which will provide for a proper amortization of this discount. Both New York commissions ${ }^{\text {ad }}$ require that bond discounts shall be charged to a special account and that annual payments be made to this fund, so that the discount will be entirely wiped out by the time of maturity. The California, ${ }^{67}$ Illinois, ${ }^{68}$ Maryland, $^{69}$ Missouri, ${ }^{70}$ and New Jersey ${ }^{71}$ commissions follow a similar practice. Several other commissions, including those of Ohio and Georgia, are on record as making no such requirements. It also appears that the Wisconsin commission does not uniformly require amortization, but this practice does not seem sound financially. The price of bonds is determined by such factors as the rate of interest, the life of the bond, the degree of security, the method of payment, and privileges, such as the right to convert into stock, given to the holder. The difference between the face value of the bonds and their selling price measures the cost to a utility of obtaining money at a given rate of interest. Discount on bonds, therefore, represents a portion of the interest payment, and amortization should be provided for. Bonds of financially sound corporations normally can be sold at par if the rate is properly adjusted. If it is fixed so that they sell at less than par, the discount simply denotes a deferred interest charge whose payment is put off until the bonds mature. Since this discount is, therefore, in the nature of interest, it should be converted into an annual interest charge, as it is when amortized. Objection is frequentiy made to the amortization requirement on the ground that it compels the consumer to pay a higher rate for his service than if no such sum were annually set aside from earnings. If, however, the rate of interest paid by the bonds were so adjusted that the bonds would sell at par, the presumption is that the annual fixed charges upon the property would be higher than if this were not done, with the same effect of higher rates to the consumer. Thus the annual payments to the amortization fund are only payments to the interest fund in disguised form.

${ }^{66}$ Application of Bronx Gas \& Elec. Co., 2 N. Y. PUb. Serv. Comm., Rep. of Decisions, 1st Dist. (1910) 10, 13; Re North Hempstead Gas Rates, 1 N. Y. Pub. Ser. Comm., 2D Dist., ANnuAL ReP. For 1924, 256, 258; Freeport v. Nassau \& Suffolk Ltg. Co., Ibid. 265, 268.

67 CAL. R. R. Comm. ReP. (1912-1913) 323, 324.

68 National Tel. \& Elec. Co., P. U. R. 1915A 872, 875.

69 MD. PUB. SER. COMM., UNIFORM SYSTEM OF ACCOUNTS (June, 1911).

701 Mo. Pub. Ser. Comm. Rer. (1913) 45-46.

${ }^{71}$ In re Hanover Water Co., 6 N. J. PUB. UtiL. Comm. ReP. (1918) 289. 
The state statutes under ordinary circumstances provide that securities may be issued to acquire property, but they do not stipulate that this acquisition must be a net addition to the property. In other words, the laws are generally silent concerning the capitalization of replacements. The Second District Commission of New York has unreservedly condemned the capitalization of replacements, holding that the outcome of this type of financing is bankruptcy. The commission further held that, if under any circumstances its approval were to be given, the replaced property should not continue to be carried on the boolis of the corporation as an asset, and the accounts should be so adjusted as to make possible a true showing of the affairs of the company.72 The First District Commission of New York has refused to allow the capitalization of replacements, but has ruled that if replacements are superior to the property displaced, the proper standard by which to determine the amount of capitalization is the relative cost of each. ${ }^{73}$ The Ohio ${ }^{74}$ and Californis ${ }^{25}$ commissions have likewise refused to permit the eapitalization of replacements. The New Hampshire commission has implied that it is not justifiable to permit the capitalization of replacements, since such expenditure is "a normal item of maintenance." 76

It appears obvious that replacements should not be capitalized. The problem, however, is complicated when adequate depreciation reserves have not been provided for and there is urgent need for the replacement of old property. In that case the alternative is to use the method prescribed by the Second District Commission of New York outlined above. Under this method a utility may be permitted to issue new securities to obtain the necessary funds for replacements, but it must eliminate from the balance sheet the property to be replaced. Capital liabilities are thus represented by true assets, which will necessitate a company's drawing either upon its surplus or its future earnings. If a company had no surplus, the stockholders apparently would have to accept lower dividends temporarily. Whether this would be penalizing present stockholders unduly because of a failure on the part of the corporation to set aside a proper depreciation fund before regulation of securities began, is a question which gives rise to considerable difference of opinion.

72 Application of Binghampton Light, H. \& P. Co., 1 N. Y. PUz. SER COMM., 2D DIST., ANNUAL REP. FOR 1910, 831.

${ }^{73} \mathrm{Re}$ N. Y. Rys. Bond Issue, 3 N. Y. PUB. Ser. Coaras., $15 T$ DrST., Rep. of Decisions (1912) 397, 407 (Case No. 1560).

rs Application of Trumbull Pub. Ser. Co., OHIo PUB. Urd. Cosar. Rep. (1914) 149.

752 Cai. R. R. Conimi, Opinions and Orders for 1913, 1026.

76 In re Milford Light \& Power Co., P. U. R. 1915D 285. 
The treatment of replacements seems to be one of the most difficult problems confronting commissions. Generally an effort should be made to prevent capitalization of replacements, but it may be more advisable in some cases to allow this than to require the public to be served by rundown and dilapidated property. Sound finance dictates that whenever the urgency of the situation renders the capitalization of replacements imperative, the approval should be accompanied by provision for the eventual reduction of capital liabilities, or the investment of earnings in net additions to the property, equal in amount to the replacements capitalized. Where a plant still has many years of wearing, capitalization of replacements can well be prevented by the commission's requirement of regularly setting aside sums for a proper depreciation fund. The problem is most complicated during the early years of commission regulation, when the depreciation reserve is not adequate to provide for replacement.

It seems that there is no unanimity among the commissions as to whether the promoter of a public utility enterprise should be allowed, as a return for his services, some of the securities approved by the commission. The Massachusetts commission has not allowed promoter's services to be capitalized. The Maryland and Ohio commissions also have not permitted anything for promoter's compensation. The New York Second District Commission, however, maintains that a fair allowance of capitalization should be properly made for such services. The Georgia, Indiana, New York First District and Wisconsin commissions all favor promoter's reward as a proper item for capitalization. The California commission exhibits a marked stand in favor of allowing the promoter an adequate and generous reward. This commission has ruled that payment for promoter's services and organization expenses "are as necessary to the success of a public utility and are as properly subjects of capitalization as the cost of the component parts of the utility's plant . . . A public authority, in estimating the value of such services, should be liberal so that men of ability may be attracted to the development of new utility enterprises where needed for the development of the State. . ." 77

It has been maintained that some reward should be permitted by the public to encourage the exercise of such talent. Undoubtedly, in some cases such an allowance is not justified, but the propriety of an allowance can be ascertained only by studying the conditions in each case. The amount to be allowed for this

77 Application of Cent. Cal. Gas. Co., 2 CAx. R. R. Comm., OpINions AND ORDERS FOR 1913, 116. For other decisions in which the California commission specifically allows the capitalization of promotion expenses and services, see Application of the Cal., Shasta \& E. Ry., 2 ibid. 326; Application of San Rafael and San Anselmo Valley Ry., 3 ibid. 879. 
purpose should depend upon the difficulty of organizing the project, the degree of ability shown, and the time required. While the amount properly allowable may be more difficult to determine than some other amounts which commissions must ascertain, nevertheless an estimate should be made of the sum necessary to secure and adequately compensate this type of service. However, in all cases where such allowance is made, care should be exercised in not permitting an allowance that is unnecessary or unduly excessive. ${ }^{78}$

Usually a financial reorganization is accompanied by an increase in capitalization, but a decrease in funded debt and other obligations upon which fixed charges must be met. An increased amount of preferred stock, income bonds, and such other security, is substituted for bonds and obligations bearing a fixed interest charge. The laws in some states pertaining to reorganization provide that capitalization shall not exceed the value of the property involved. MIost laws simply place recapitalization in the hands of the commissions by requiring that all securities issued must be approved by the commission, but without giving specific instructions concerning the policy to be followed in reorganizations.

Some state commissions have formulated certain principles to which they adhere in passing upon securities issued under a reorganization project. The New York First District Commission in the Third Avenue Railroad case maintained that in reorganization, it would be unsound financially for the commission to authorize the issuance of securities upon which it was improbable that returns would be earned. ${ }^{\circ}$ The railroad company in this case held that the rule of law was established that in reorganization the reorganized company might issue securities equal in amount to the previous capitalization. The commission in rejecting this contention of the company said:

"A necessary corollary of this theory is that capitalization need have no relation to value. If once a company is started and its securities carefully issued . . . an equity would be created which would give any successor company purchasing the property at foreclosure a perpetual right to issue stock and bonds to the same amount regardless of what happens to the property. The original company might allow the property to decay, it might declare dividends out of capital, it might abuse every corporate privilege and lose 90 per cent of the original investment, and yet the purchasers could reasonably insist that this Commission should approve the issuance of securities equal in amount to the stock and bonds issued by the original company. It violates the sound principle that capitalization should have some direct relation to the value of the property it represents." 6

${ }^{78} C f$. Heilman, op. cit. supra note 8, at 904 .

792 N. Y. PUB. Ser. Commr., 1St Dist., ANNuAr Rep. for 1909, 42, 54.

80 The company in question appealed from the commission's decision to 
The New York Second District Commission has ruled that in reorganizations the capitalization should be reduced to correspond to the value of the property included. The commission maintains that reorganization indicates the presence of overcapitalization, that, therefore, the purpose of reorganization should be to reduce capitalization to a proper basis, and that in recapitalization stock and bonds may be issued only in amount equal to the fair value of the property. ${ }^{81}$ The Missouri commission has taken a substantially similar position, while the California commission has stressed the importance of earnings as a factor in ascertaining proper capitalization in reorganizations.

The principle developed by the New York First District Commission and applied by other commissions, that capitalization in reorganizations should be based on the value of property and earnings, is essentially sound if reasonably applied. Occasionally, however, objection is raised to a reduction in capitalization on the ground that injustice is worked upon those who hold the old securities and who are thus obliged to accept a lesser number, or: a smaller par value of the new securities. Ujpon this subject the New York Second District Commission has held that no injustice is wrought upon the bondholders, since, in any case, they are protected only by the value of the property pledged as security for their bonds and by the earning capacity of the property. Furthermore, a reduction in capitalization is likewise held not necessarily to cause an injustice to the stockholders, as their equity in the property does not exceed the difference between the value of the property and the bonds and other obligations against it. It is also held that their income cannot exceed the difference between total earnings and operating expenses and fixed charges, irrespective of the par value or the number of their shares. This argument is based on the assumption that a stockholder is entitled only to his proper proportion of the dividends, and to his proper proportion of the proceeds of the sale of the assets of the corporation if it should be dissolved at any time. Of course, under some circumstances it is obvious that two shares of stock of $\$ 100$ par value each might be sold for more than one share of $\$ 100$, although the one represents the same share in the ownership of the property as the two. This fact is in part responsible for the tendency toward over-capitalization, and reg-

the Court of Appeals, which decided the case adversely to the ruling of the commission. This decision was based upon the fact that a section in the Corporations Act, which gave corporations freedom in the matter of recapitalization, had not been repealed by the Public Utility Commission Law. Later this statute was repealed, so that the commission now is free to follow the policy adhered to in the Third Avenue Case.

${ }^{81}$ Petition of Genesee Light \& Power Co., 1 N. Y. PUB. SER. Comm., 2D Dist., ANNUAL Rep. FOR 1919, 228, 578. 
ulation should aim to prevent excessive capitalization which is likely to result from this fact. If the capitalization of a bankrupt company is so great that earnings based upon the fair value of property are not sufficient to properly provide for interest and dividends, approval by a commission of the old capitalization as the proper basis for the new would in reality mean that the commission would aid security holders in the defunct utility corporation to unload their losses upon the investor. State control cannot undo all the evils resulting from securities issued excessively prior to the era of regulation, but when capitalization is so out of proportion to earning capacity and the value of the property that reorganization is inevitable, the time is opportune to scale down capitalization.

Many state laws allow stock dividends to be issued in an amount equal to the difference between the actual value of the assets and present capitalization. The net assets and property of the company in excess of other liabilities must be equal to the par value of the total stock outstanding after such stock dividends have been declared. The commissions of California, ${ }^{\text {cs }}$ Illinois, ${ }^{83}$ Indiana ${ }^{84}$ and New Jersey ${ }^{\text {ss }}$ have rendered opinions to the same effect. In certain instances the issuance of stock dividends has some advantages. Surplus is essential to every corporation for the purpose of providing for emergencies and stabilizing dividends. An economic waste results if this surplus is kept in the form of idle cash. If it is placed in outside investments over which the management has no control, a risk is incurred which could only be minimized by investing it in preferred securities yielding small returns. When the surplus is invested in a company's own business, improvements can be made regardless of conditions in the money market. With the present powers possessed by utility commissions, there is little danger involved in permitting the investment of a corporation's surplus in its own property and the distribution of a stock dividend when the property improvements are completed. This would be particularly just in cases where the owners have denied themselves dividends in order to build up the credit of the corporation.

The courts have established fundamental principles regaiding the valuation of utility property and rate malking, but they have not formulated definite and specific principles with reference to control of utility capitalization. In this important field of utility operation the commissions have worked out well-defined principles which are generally followed by them. While some of

82 In re Pacific Gas. \& Elect. Co., P. U. R. 1915C 324.

83 In re IIaroa MIut. Telephone Co., P. U. R. 1915A 205.

S1 In re Linton Water Co., P. U. R. 1915A 540.

${ }^{85}$ In re Raritan River R. R., P. U. R. $1915 \mathrm{E} 72$. 
these principles may be questioned, yet as a whole they are beneficial to the public. Regulation of utility securities of the type discussed in this treatise will in all probability render impossible the sort of financial manipulation and jugglery that has characterized the management of the public utilities in the past. This scheme of control has not eradicated all the evils hitherto inherent in utility capitalization, but it has at least minimized the burden which these evils formerly imposed upon the public, especially in states where the commissions have ample power to regulate issues of utility securities. Many of the state laws controlling security issues lack uniformity, and are still inadequate properly to safeguard the investor, but in spite of these defects it is only fair to say that the attempt at regulation has been justified and in the main satisfactory. 